\title{
Cenomanian vertebrate assemblages from southwestern France: a new insight into the European mid-Cretaceous continental fauna
}

\author{
Romain Vullo*, Didier Néraudeau \\ Laboratoire de Paléontologie, Géosciences, UMR 6118, Université de Rennes 1, 263 avenue du Général Leclerc, \\ 35042 Rennes cedex, France \\ * Corresponding author \\ E-mail address: romain.vullo@univ-rennes1.fr
}

\begin{abstract}
Cenomanian paralic deposits of Charentes (southwestern France) have yielded abundant vertebrate microremains, including rather diversified continental taxa (e.g., frogs, turtles, crocodilians, dinosaurs, pterosaurs, lizards, and mammals). In this preliminary report, the succession of faunal assemblages observed is briefly described in relation to palaeoenvironmental change resulting from the Cenomanian-early Turonian transgressive episode. Continental forms occur commonly in estuarine and shallow marine rocks of the lower part of the Cenomanian stage, but seem to be lacking in younger strata deposited in more open marine settings. Among an unexpected biodiversity, several non-marine groups (e.g., ziphodont crocodilians, carcharodontosaurid and troodontid dinosaurs, marsupial-like mammals) are
\end{abstract}


recorded for the first time in the lower Upper Cretaceous of Europe, thus providing new palaeobiogeographical indications for this poorly documented part of the world.

Keywords: Vertebrates; Cenomanian; SW France; Continental fauna; Palaeoecology; Palaeogeography.

\section{Introduction}

The middle part of the Cretaceous Period, especially the Cenomanian Epoch, corresponds to a period marked by important tectonic, eustatic and biotic changes. The Cenomanian is characterized by a global sea-level highstand (Haq et al., 1987) and Europe formed an archipelago where almost no continental deposits have been preserved (Smith et al., 2001). So non-marine vertebrates are generally rare in Cenomanian rocks from Europe, and data concerning terrestrial faunas are thus very incomplete for this period (Buffetaut et al., 1981). Fossiliferous localities are sparsely distributed and they have generally yielded isolated remains or poorly diversified assemblages, mostly composed of a few rather large elements (macroremains) (Buffetaut, 1989; Fejfar et al., 2005). Landemaine (1991) studied the selachian fauna from the Cenomanian of southwestern France and then noted the occurrence of rather numerous non-marine tetrapod teeth and bones within fish-dominated assemblages. Subsequently Buffetaut and Pouit (1994) and Buffetaut and Brignon (1999) described crocodilian and dinosaurian microremains from shallow marine, detrital deposits of various western France localities. These authors underlined the interest of such localities for a better 
knowledge of the continental fauna living in the European archipelago during the Cenomanian. Since 2000, we have intensively prospected for fossil vertebrates in the Cenomanian of the Charentes region (southwestern France). This field work is still in progress and has led to the discovery of new vertebrate-bearing deposits (microremains) which has allowed a more advanced study of the previously known assemblages (Néraudeau et al., 2003, 2005; Vullo et al. 2003, 2005, 2007; Vullo, 2005). The material, including more than 18.000 identified elements, mostly comes from a large bulk sampling and sieving program. Only a small proportion of the remains has been surface collected in the field. Herein we present the preliminary results of these investigations.

\section{Location and geological setting}

Cenomanian deposits widely crop out in Charentes, corresponding to the northwestern part of the Aquitaine Basin (southwestern France). In this region, the stratigraphy of sediments corresponding to the Cenomanian stage has been divided into seven lithological units (A-G) by Néraudeau et al. (1997), and some units have been further subdivided into a few sub-units (e.g. B1, B2 and B3 for B). The main vertebrate deposits are located in sub-units B1 and B2, which correspond in age to the early Cenomanian, and in the units or sub-units C4, D, E and G1 corresponding in age to the late Cenomanian. The vertebrate localities are distributed along an axis extending from the Rochefort area, in the west, to the Angoulême area, in the east (Fig. 1A).

The Charentes region emerged during the Early Cretaceous, and recorded progressively marine conditions as the consequence of the Cenomanian transgression. The first part of the series (lithological sub-units A2, B1, B2) corresponds to shallow and paralic coastal 
environments (estuaries, mangroves, lagoons) (Néraudeau et al., 2002, 2003, 2005; Vullo et al., 2003). The middle Cenomanian sub-units $\mathrm{C} 1, \mathrm{C} 2$ and $\mathrm{C} 3$ are marked by the development of rudist patch reefs. Lastly, the upper Cenomanian units begin by rather proximal facies (units C4, D, E) and evolves to more open marine environments around the Cenomanian/Turonian boundary (upper Cenomanian sub-units G1-G2, and basal Turonian sub-unit T1) (Fig. 1B).

\section{Vertebrate assemblages}

\subsection{The earliest Cenomanian assemblages}

The assemblages coming from the B1 sub-unit (about 50 taxa in total) are characterized by a diverse shallow marine selachian fauna (about 30 taxa including numerous small-sized orectolobiforms and rajiforms). Teeth of the euryhaline hybodont shark Tribodus (Fig. 2A) are abundant. Actinopterygian fish remains are common, but the material is fragmentary and weakly diagnostic. Teeth of semionotids, pycnodontids, enchodontids and amiids have been recognized, as well as some coarsely folded ganoid scales originally described by Weiler (1935) as "Stromerichthys" (Fig. 2C), a fish taxon of doubtful affinities. It is commonly regarded as a possible amiiform (Dutheil, 1999), even if some enamel folds can also develop on scales of gars (lepisosteids) (Buffetaut et al., 1996; Cavin et al., 1996; Gottfried and Krause, 1998).

Plesiosaurs and primitive marine snakes (Simoliophis) (Fig. 2L) are well represented in these assemblages, with rather numerous teeth and vertebrae, respectively. All these marine organisms have been collected in association with rather numerous microremains of continental tetrapods, mainly represented by turtles (Solemydidae, ?Dortokidae) (Fig. 2E), crocodilians (Atoposauridae, Bernissartidae, Goniopholidae, Pholidosauridae) (Fig. 2F) and rare pterosaurs 
(?Ornithocheiridae). Dinosaurs are only known by a few incomplete theropod teeth, which can be mostly assigned to Carcharodontosaurus because of their crown morphology and enamel ornamentation, similar to the dental diagnostic features described by Sereno et al. (1996) for $C$. saharicus. A unique complete tooth, basally constricted, lacking denticles on anterior carina and bearing three large denticles on posterior carina, is very close to the teeth of Troodontidae (see Currie, 1987) (Fig. 2H). Lastly, some very rare remains of an anuran amphibian (Fig. 2D) and of a tribosphenic mammal close to primitive marsupials (small lower molar with a low trigonid, a wide talonid and well-developed paraconid and entoconid) (Fig. 2M) have been collected, thus constituting the first occurrence of these two groups in the early Late Cretaceous of Europe. It must be noted that a relatively large tooth (premolar) of an indeterminate mammal has recently been described by Néraudeau et al. (2005).

\subsection{The mid-Early Cenomanian assemblages}

The assemblages from the B2 sub-unit show the same faunal pattern as in the B1 sub-unit. Nevertheless, a slight change can be observed among the continental components with the addition of several taxa. The selachian fauna is very similar to that collected from the earliest Cenomanian localities. The actinopterygian fish material includes in particular one tooth tentatively assigned to the Lepisosteidae (Fig. 2B). This small tooth has a conical crown devoid of carinae, and shows a folded basal part and a smooth apical part. However, the discovery of typical opisthocoelus vertebrae would be needed in order to confirm this identification. Chelonians, here represented by numerous shell fragments of Solemydidae (Fig. 2E), are locally more abundant. The carapace of these turtles displays a characteristic granular or 
vermiculated surface. Crocodilians and dinosaurs appear to be more diversified. Two small teeth with serrated carinae can be referred to a ziphosuchian crocodilian (Vullo et al., 2005), and several dinosaur teeth indicate the presence of an indeterminate titanosauriform sauropod (Fig. 2G), a dromaeosaurid theropod, a small-sized ornithopod (a derived non-hadrosaurid iguanodontoid) (Néraudeau et al., 2003; Vullo et al., 2005) and a nodosaurid ankylosaur. Additionally, complete and very diagnostic teeth of Carcharodontosaurus (posterior carina convex close to the apex; slight transverse enamel folds curved near margins) have been collected. These teeth are undistinguishable from those of $C$. saharicus coming from Algeria (Depéret and Savornin, 1927), Morocco (Amiot et al., 2004; pers. obs.) and Tunisia (Bouaziz et al., 1988). A rather large pterosaur (one tooth and hollow bones tentatively referred to ?Ornithocheiridae) (Fig. 2I, J) and a scincomorph-like lizard represented by only one fragmentary jaw (Fig. 2K) also occur in these assemblages. Marine squamates are mainly represented by abundant vertebrae of Simoliophis (Fig. 2L). The lack of small forms like frogs and mammals in the samples may be due to taphonomical or collecting bias.

\subsection{The earliest Late Cenomanian assemblages}

The fauna from the units C4 and D consists of about 20 taxa, with almost exclusively marine fishes. Batoids become rarer, while the large lamniform shark Cretolamna appendiculata appears in the assemblages. Tetrapods are represented by isolated vertebrae of Carentonosaurus, an aigialosaur marine varanoid (Rage and Néraudeau, 2004) and by a unique tooth of pterosaur (?Ornithocheiridae). The assemblages are devoid here of strictly continental vertebrates, like dinosaurs. 


\subsection{The latest Cenomanian-earliest Turonian assemblage}

The only locality (Port-des-Barques) corresponding to the Cenomanian/Turonian boundary (sub-units G2 and T1) shows non-condensed deposits that have not produce any true vertebrate assemblages. The very few vertebrate remains that have been collected around the Cenomanian/Turonian boundary correspond exclusively to marine fish, mainly teeth of large lamniform sharks (Cretodus, Cretolamna, Squalicorax). A unique tooth of the marine hybodont shark Ptychodus has been collected in the G2 sub-unit deposits, corresponding to the only occurrence of this genus in the Cenomanian of Charentes. Marine reptiles have not been recovered so far.

\section{Discussion}

The vertebrate faunal succession observed in the Cenomanian series of Charentes illustrates the progressive change of depositional environments from estuarine to open marine biotas (Tab. 1), which was originally recorded from sedimentological data, and which occurred as a consequence of the Cenomanian transgression. Besides fish, the shallow paralic deposits of early Cenomanian age have also yielded rather numerous microremains of continental forms (frogs, turtles, crocodilians, dinosaurs, pterosaurs, lizards, snakes, mammals).

Until now, no vertebrate remains have been recovered from the middle Cenomanian perireefal rocks. In this non-terrigenous carbonate facies, this obvious absence could be due to a taphonomical bias. At the end of the Cenomanian stage, the generally deeper deposits are 
characterized by the lack of continental vertebrate remains within poorly diversified assemblages. The diversification of the ammonite fauna (Moreau et al., 1983) and the appearance of the shark genera Cretolamna and Ptychodus in Charentes during the late Cenomanian indicate a more open marine environment. At the scale of the whole stage, the palaeoenvironmental evolution of the vertebrate assemblages from the Cenomanian of Charentes displays a pattern similar to that observed within the Cenomanian-Turonian series of the Tafilalt basin (SE Morocco) (Cavin et al., 2001). In both cases, continental (e.g., dinosaurs) and brackish (e.g., hybodont sharks like Tribodus) vertebrates are restricted to the basal part of the series (corresponding to the "Kem Kem beds" in the Tafilalt basin) whereas the upper part (corresponding to the Goulmima locality in the Tafilalt basin) yields open marine fish and reptiles (e.g., aigialosaurs).

Several groups are recorded for the first time in the early Late Cretaceous of Europe, implying new palaeobiogeographical interpretations. The non-marine taxa identified in the Cenomanian of Charentes can be divided into two groups characterizing two distinct palaeobiogeographical realms. The first group includes Laurasian forms, which also occur in the Cenomanian of North America. There, the two most similar assemblages are the Woodbine Formation fauna (Texas) (Lee, 1997; Head, 1998; Jacobs and Winkler, 1998) and the Mussentuchit local fauna of the Cedar Moutain Formation (Utah) (Cifelli et al., 1999). The discovery of troodontid dinosaurs and primitive marsupial-like mammals, previously unknown from the early Late Cretaceous of Europe, indicates a probable land route between North America and Western Europe. In addition, solemydid turtles, non-ziphosuchian crocodilians like atoposaurids (Fig. 2), nodosaurid and primitive hadrosaurid dinosaurs also belong to the Laurasian fauna. The second palaeobiogeographic group recognized in Charentes shares 
affinities with the Gondwanan fauna. It includes the hybodont Tribodus, ziphosuchian crocodilians and the primitive snake Simoliophis (Vullo et al., 2005). The new discovery in the Cenomanian of Charentes of teeth referable to a probable lepisosteid fish and to the theropod genus Carcharodontosaurus strengthens the hypothesis of mid-Cretaceous trans-Tethyan continental connections between North Africa and southwestern Europe. Lepisosteids are indeed well known in the Cenomanian of Morocco (Cavin and Brito, 2001) and Portugal (Jonet, 1981). The Portuguese and French occurrences of such fish originated from Gondwana would correspond to their earliest record in Europe. In addition, the similar palaeobiogeographic distribution of "Stromerichthys" (Jonet, 1981; Dutheil, 1999) is noteworthy. Concerning the theropod Carcharodontosaurus, Sereno et al. (1996) and Amiot et al. (2004) noted that this genus is probably a taxon of Gondwanan affinities. Its presence in Europe and North Africa during the Cenomanian may result from a faunal dispersion between both continents. In conclusion, the assemblages from Charentes display, for non-marine vertebrates, a doubleinfluenced faunal composition (Laurasian and Gondwanan affinities) due to the particular palaeogeographical position of southwestern Europe, situated halfway between North America and North Africa.

The diverse paralic facies of the Cenomanian series of Charentes largely contribute to increase our knowledge about early Late Cretaceous vertebrate faunas (marine and continental) from Europe. This article constitutes a preliminary report and more detailed systematic studies are needed for each taxonomic group. Even if the identification of several taxa is based on poorly diagnostic or too scarce material, the diversity and the faunal composition of these assemblages appear relatively complex, with new palaeoecological and palaeobiogeographical implications. 


\section{Acknowledgements}

We would thank everyone who helped us during the long field work as well as for sieving and sorting. We are most grateful to everyone who put some fossil material at our disposal. R. Allain, A.O. Averianov, H. Cappetta, K. Carpenter, S.E. Evans, M. Gayet, E. Gheerbrant, J.I. Kirkland, F. de Lapparent de Broin, C. de Muizon, and J.-C. Rage are especially thanked for helpful discussion. We lastly thank L. Cavin and anonymous reviewers, for their helpful criticism and comments.

\section{References}

Amiot, R., Buffetaut, E., Tong, H., Boudad, L., Kabiri, L., 2004. Isolated theropod teeth from the Cenomanian of Morocco and their palaebiogeographical significance. Revue de Paléobiologie, volume spécial 9, 143-149.

Bouaziz, S., Buffetaut, E., Ghanmi, M., Jaeger, J.-J., Martin, M., Mazin, J.-M., Tong, H., 1988. Nouvelles découvertes de vertébrés fossiles dans l'Albien du sud tunisien. Bulletin de la Société géologique de France 4, 335-339.

Buffetaut, E., 1989. Une vertèbre de dinosaure titanosauridé dans le Cénomanien du Mans et ses implications paléobiogéographiques. Comptes Rendus de l'Académie des Sciences, Paris, série IIa 309, 437-443. 
Buffetaut, E., Brignon, A., 1999. Une dent de Nodosauridé (Dinosauria, Ankylosauria) dans le Cénomanien de Touraine. Géologie de la France 1, 49-52.

Buffetaut, E., Pouit, D., 1994. Restes de dinosaures et de crocodiliens dans le Crétacé supérieur du Centre-Ouest de la France. Comptes Rendus de l'Académie des Sciences, Paris, série IIa 319, 253-259.

Buffetaut, E., Cappetta, H., Gayet, M., Martin, M., Moody, R.T.J., Rage, J.-C., Taquet, P., Wellnhofer, P., 1981. Les vertébrés de la partie moyenne du Crétacé en Europe. Cretaceous Research 2, 275-281.

Buffetaut, E., Costa, G., Le Lœuff, J., Martin, M., Cavin, L., Rage, J.-C., Valentin, X., Tong, H., 1996. An early Campanian vertebrate fauna from the Villeveyrac Basin (Hérault, southern France). Neues Jahrbuch für Geologie und Paläontologie, Monatschefte 1996, 116.

Cavin, L., Brito, P.M., 2001. A new Lepisosteidae (Actinopterygii: Ginglymodi) from the Cretaceous of the Kem Kem beds, southern Morocco. Bulletin de la Société géologique de France 172, 661-670. 
Cavin, L., Martin, M., Valentin, X., 1996. Découverte d'Atractosteus africanus (Actinopterygii, Lepisosteidae) dans le Campanien inférieur de Ventabren (Boûches-du-Rhône, France). Implications paléobiogéographiques. Revue de Paléobiologie 15, 1-7.

Cavin, L., Boudad, L., Duffaud, S., Kabiri, L., Le Lœuff, J., Rouget, I., Tong, H., 2001. L'évolution paléoenvironnementale des faune de poissons du Crétacé supérieur du bassin de Tafilalt et des régions avoisinantes (Sud-Est du Maroc) : implications paléobiogéographiques. Comptes Rendus de l’Académie des Sciences, Paris, série IIa 333, $677-683$.

Cifelli, R.L., Nydam, R.L., Gardner, J.D., Weil, A., Eaton, J.G., Kirkland, J.I., Madsen, S.K., 1999. Medial Cretaceous vertebrates from the Cedar Mountain Formation, Emery County, Utah: the Mussentuchit local fauna. In: Gillette, D.D. (Ed.), Vertebrate Paleontology in Utah. Miscellaneous Publications 99-1, Utah Geological Survey, Salt Lake City, 219-242.

Currie, P.J., 1987. Bird-like characteristics of the jaws and teeth of troodontid theropods (Dinosauria, Saurischia). Journal of Vertebrate Paleontology 7, 72-81.

Depéret, C., Savornin, J., 1927. La faune de reptiles et de poissons albiens de Timimoun (Sahara algérien). Bulletin de la Société géologique de France 27, 257-265.

Dutheil, D., 1999. An overview of the freshwater fish fauna from the Kem Kem beds (Late Cretaceous: Cenomanian) of southeastern Morocco. In: Arratia, G., Schultze, H.-P. (Eds.), 
Mesozoic Fishes 2 - Systematics and Fossil Record. Verlag Dr. Friedrich Pfeil, München, 553-563.

Fejfar, O., Košt’ák, M., Kvaček, J., Mazuch, M., Moučka, M., 2005. First Cenomanian dinosaur from Central Europe (Czech Republic). Acta Palaeontologica Polonica 50, 295-300.

Gottfried, M.D., Krause, D.W., 1998. First record of gars (Lepisosteidae, Actinopterygii) on Madagascar: Late Cretaceous remains from the Mahajanga Basin. Journal of Vertebrate Paleontology 18, 275-279.

Haq, B.U., Hardenbol, J., Vail, P.R., 1987. Chronology of fluctuating sea levels since the Triassic. Science 235, 1156-1167.

Head, J.J., 1998. A new species of basal hadrosaurid (Dinosauria, Ornithischia) from the Cenomanian of Texas. Journal of Vertebrate Paleontology 18, 718-738.

Jacobs, L.L., Winkler, D.A., 1998. Mammals, archosaurs and the Early to Late Cretaceous transition in north-central Texas. In: Tomida, Y., L.J. Flynn, L.J., Jacobs L.L. (Eds.), Advances in Vertebrate Paleontology and Geochronology. National Science Museum Monographs 14, Tokyo, 253-280. 
Jonet, S., 1981. Contribution à l'étude des vertébrés du Crétacé portugais et spécialement du Cénomanien de l'Estrémadure. Comunicações dos Serviços Geológicos de Portugal 67, 191300.

Landemaine, O., 1991. Sélaciens nouveaux du Crétacé supérieur du sud-ouest de la France. Quelques apports à la systématique des élasmobranches. Société Amicale des Géologues Amateurs (MNHN, Paris), SAGA information hors-série 1, 1-45.

Lee, Y.-N., 1997. The Archosauria from the Woodbine Formation (Cenomanian) in Texas. Journal of Paleontology 71, 1147-1156.

Moreau, P., Francis, I.H., Kennedy, W.J., 1983. Cenomanian ammonites from northern Aquitaine. Cretaceous Research 4, 317-339.

Néraudeau, D., Thierry, J., Moreau, P., 1997. Variation in echinoid biodiversity during the Cenomanian-early Turonian transgressive episode in Charentes. Bulletin de la Société géologique de France 168, 51-61.

Néraudeau, D., Perrichot, V., Dejax, J., Masure, E., Nel, A., Philippe, M., Moreau, P., Guillocheau, F., Guyot, T., 2002. Un nouveau gisement à ambre insectifère et à végétaux (Albien terminal probable): Archingeay (Charente-Maritime, France). Geobios 35, 233-240. 
Néraudeau, D., Allain, R., Perrichot, V., Videt, B., de Lapparent de Broin, F., Guillocheau, F., Philippe, M., Rage, J.-C., Vullo, R., 2003. Découverte d'un dépôt paralique à bois fossile, ambre insectifère et restes d'Iguanodontidae (Dinosauria, Ornithopoda) dans le Cénomanien inférieur de Fouras (Charente-Maritime, Sud-Ouest de la France). Comptes Rendus Palevol $2,221-230$.

Néraudeau, D., Vullo, R., Gomez, B., Perrichot, V., Videt, B., 2005. Stratigraphie et paléontologie (plantes, vertébrés) de la série paralique Albien terminal-Cénomanien basal de Tonnay-Charente (Charente-Maritime, France). Comptes rendus Palevol 4, 79-93.

Rage, J.-C., Néraudeau, D., 2004. A new pachyostotic squamate reptile from the Cenomanian of France. Palaeontology 47, 1195-1210.

Sereno, P.C., Dutheil, D.B., Iarochene, M., Larsson, H.C.E., Lyon, G.H., Magwene, P.M., Sidor, C.A., Varricchio, D.J., Wilson, J.A., 1996. Predatory dinosaurs from the Sahara and Late Cretaceous faunal differentiation. Science 272, 986-991.

Smith, A.B., Gale, A.S., Monks, N.E.A., 2001. Sea-level change and rock-record bias in the Cretaceous: a problem for extinction and biodiversity studies. Paleobiology 27, 241-253.

Vullo, R., 2005. Les vertébrés du Crétacé supérieur des Charentes (Sud-Ouest de la France): biodiversité, taphonomie, paléoécologie et paléobiogéographie. Unpublished $\mathrm{PhD}$ thesis, University of Rennes 1, 302 pp. 
Vullo, R., Cappetta, H., Néraudeau, D., 2007. New sharks and rays from the Cenomanian and Turonian of Charentes, France. Acta Palaeontologica Polonica 52, 99-116.

Vullo, R., Néraudeau, D., Videt, B., 2003. Un faciès de type falun dans le Cénomanien basal de Charente-Maritime (France). Annales de Paléontologie 89, 171-189.

Vullo, R., Néraudeau, D., Allain, R., Cappetta, H., 2005. Un nouveau gisement à microrestes de vertébrés continentaux et littoraux dans le Cénomanien inférieur de Fouras (CharenteMaritime, Sud-Ouest de la France). Comptes Rendus Palevol 4, 95-107.

Weiler, W., 1935. Ergebnisse der Forschungsreisen Prof. E. Stromer's in den Wüsten Ägyptens.II. Wirbeltierreste der Baharije-Stufe (unterstes Cenoman). 16. Neue Untersuchungen an den Fischresten. Abhandlungen der Bayerischen Akademie der Wissenschaften, Mathematisch-naturwissenschaftlichen Abteilung (N.F.) 32, 1-57. 


\section{Figures and tables:}

Fig. 1. A, map of the Charentes region showing the Cenomanian outcrops and the geographical positions of the ten localities studied. B, stratigraphical positions of the localities. The localities 1 to 3 (circles) are earliest Cenomanian in age (B1), the localities 4 to 6 (hexagons) are early Cenomanian in age (B2), the localities 7 to 9 (squares) are late Cenomanian in age (C4-D) and the locality 10 (star) is latest Cenomanian-earliest Turonian in age (G1-T1).

Fig. 2. Vertebrate remains from the lower Cenomanian of Charentes. A, Tribodus morlati (Landemaine), tooth in lingual view, Les Renardières. B, ?Lepisosteidae, tooth in lateral view, Fouras-Vauban. C, "Stromerichthys" sp., ganoid scale in lateral view (outer face), Les Renardières. D, Anura indet., right scapula in lateral view (inner face), Font-de-Benon. E, Solemydidae, peripheral plate in dorsal view, Fouras Bois-Vert. F, Atoposauridae, tooth in lingual view, Montagan. G, Titanosauriformes indet., tooth in labial view, Fouras-Vauban. H, Troodontidae, tooth in lingual view, Font-de-Benon. I, J, ?Ornithocheiridae, fragmentary hollow bone in longitudinal view (I) and drawn of the transversal section (J), Fouras Bois-Vert. K, ?Scincomorpha indet., fragmentary right dentary bearing two teeth in labial view, FourasVauban. L, Simoliophis rochebrunei Sauvage, vertebra in anterior view, Montagan. M, ?Marsupialia indet., right talonid in occlusal view, Font-de-Benon. Scale bars represent $1 \mathrm{~mm}$ (A-D, F, H, K, M), $5 \mathrm{~mm}(\mathrm{G}, \mathrm{L})$ and $10 \mathrm{~mm}(\mathrm{E}, \mathrm{I}, \mathrm{J})$.

Table 1. Ages, palaeoenvironments, and faunal patterns of the Cenomanian vertebrate localities from Charentes. 
Table 1

\begin{tabular}{|c|c|c|c|}
\hline Localities & Age & $\begin{array}{l}\text { Sedimentology and } \\
\text { depositional environments }\end{array}$ & $\begin{array}{l}\text { Faunal pattern of the } \\
\text { assemblages (main particular } \\
\text { taxa being indicated) }\end{array}$ \\
\hline Port-des-Barques & $\begin{array}{l}\text { latest Cenomanian / } \\
\text { earliest Turonian (G-T } \\
\text { units) }\end{array}$ & $\begin{array}{l}\text { inner to outer shelf marls, } \\
\text { open marine conditions }\end{array}$ & $\begin{array}{l}\text { only marine forms (large } \\
\text { lamniform sharks) }\end{array}$ \\
\hline $\begin{array}{l}\text { Madame Island, } \\
\text { L’Amas, Le Mas }\end{array}$ & $\begin{array}{l}\text { earliest late Cenomanian } \\
\text { (C4-D units) }\end{array}$ & $\begin{array}{l}\text { clays and silty marls, shallow } \\
\text { marine lagoon }\end{array}$ & $\begin{array}{l}\text { only marine forms (lamniform } \\
\text { sharks, pycnodontid fishes, } \\
\text { aigialosaurids), except pterosaurs }\end{array}$ \\
\hline $\begin{array}{l}\text { Fouras Bois-Vert, } \\
\text { Fouras-Vauban, } \\
\text { La Buzinie, } \\
\text { Traslemaine, } \\
\text { Montagan }\end{array}$ & $\begin{array}{l}\text { middle early } \\
\text { Cenomanian (B2 unit) }\end{array}$ & $\begin{array}{l}\text { estuarine glauconitic clays and } \\
\text { sands ; paralic / shoreface } \\
\text { conglomerates and lag } \\
\text { deposits }\end{array}$ & $\begin{array}{l}\text { maximum diversity of marine } \\
\text { and continental forms; only } \\
\text { occurrence of ziphosuchian } \\
\text { crocodilians, sauropods, } \\
\text { ornithopods, ankylosaurs and } \\
\text { scincomorph lizards }\end{array}$ \\
\hline $\begin{array}{l}\text { Les Renardières, } \\
\text { Font-de-Benon, } \\
\text { Cadeuil }\end{array}$ & $\begin{array}{l}\text { earliest Cenomanian (B1 } \\
\text { unit) }\end{array}$ & paralic / shoreface silty sands & $\begin{array}{l}\text { high diversity of marine and } \\
\text { continental forms; only } \\
\text { occurrence of anurans, } \\
\text { indeterminate snakes and } \\
\text { mammals }\end{array}$ \\
\hline
\end{tabular}




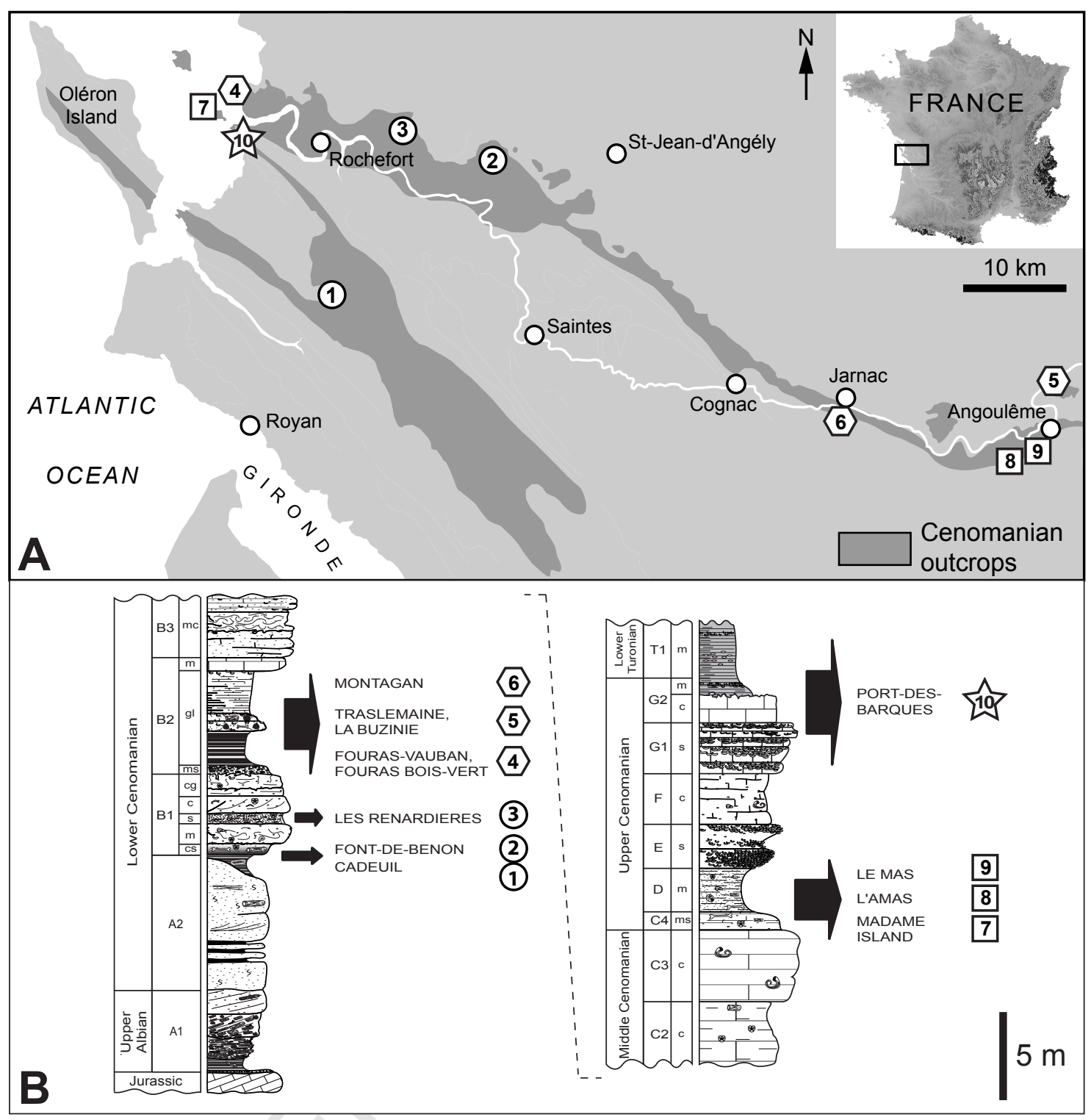




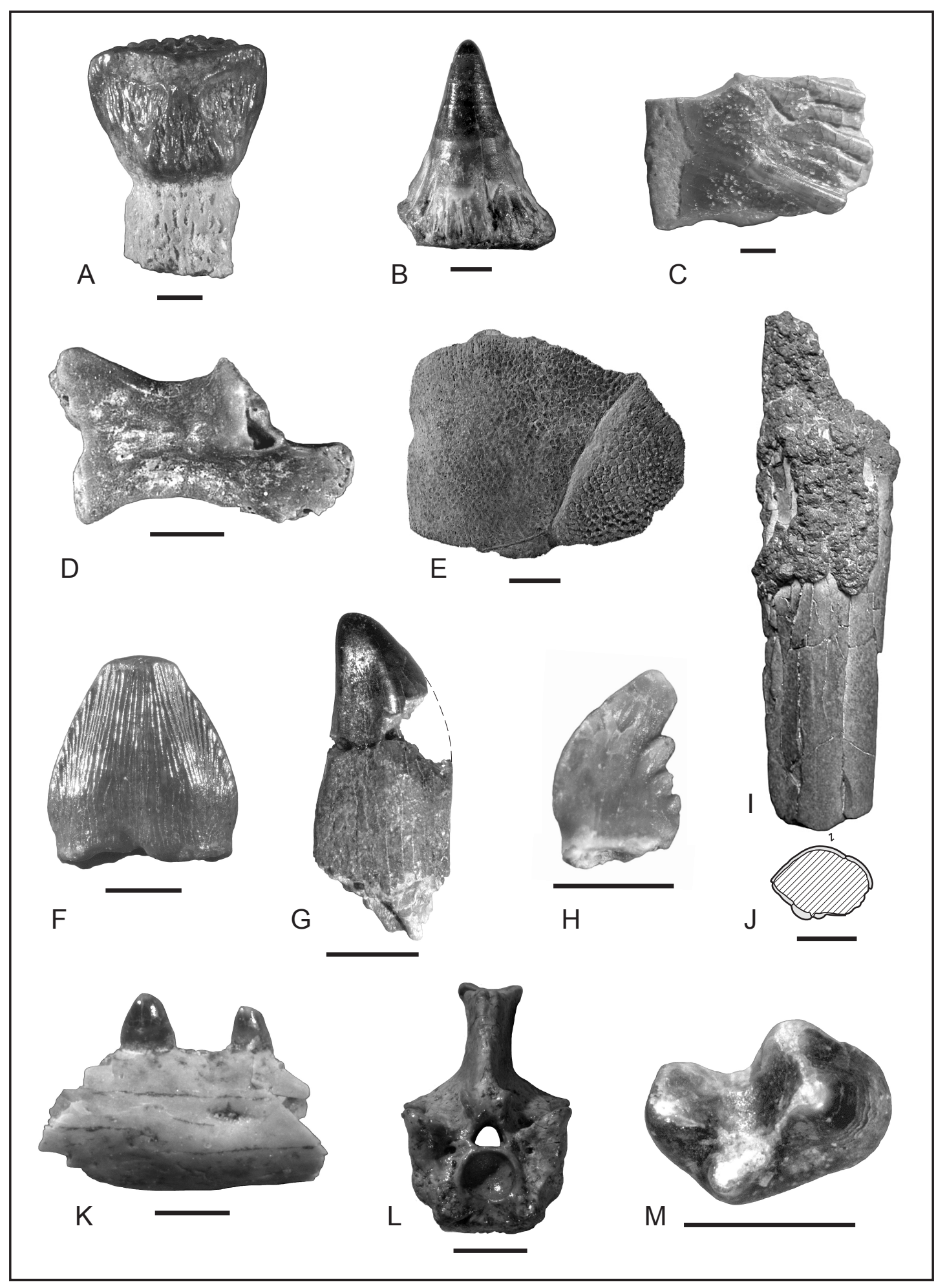

